\title{
PENDAMPINGAN INOVASI MANAJEMEN PENGELOLAAN KELAS DALAM PEMBELAJARAN PENDIDIKAN AGAMA ISLAM DI SMP SUNAN KALIJOGO JABUNG
}

\author{
Endang Tyasmaning1) \\ Institut Agama Islam Sunan Kalijogo Malang \\ endangtyasmaning@iaiskjmalang.ac.id
}

\begin{abstract}
Abstrak. SMP Sunan Kalijogo Jabung merupakan sekolah yang berada dalam naungan pondok pesantren Sunan Kalijogo Jabung, maka itu Pendidikan agama sangat ditekankan pada para siswa yang menempuh Pendidikan di sekolah ini. Maka untuk mewujudkan hal itu maka dilaksanakan kegiatan pengabdian dalam bentuk pendampingan inovasi manajemen pengelolaan kelas dalam pembelajaran pendidikan agama islam. Tujuan pelaksanaan pendampingan ini agar dapat meningkatkan lagi hasil pembelajaran di bidang Pendidikan agama islam agar lebih berkualitas dan memberikan pengaruh yang baik bagi siswa atau guru. Maka itu pendampingan ini difokuskan pada manajemen pengelolaan kelas guna meningkatkan hasil pembelajaran, pelaksanaan kegiatan ini dilakukan pada bulan juli dengan mengundang beberapa nara sumber yang kompeten di bidang Pendidikan agama islam dan manajemen pengelolaan kelas. Luaran dari pengabdian ini berupa buku ber-ISBN dan sebuah artikel yang di publish pada jurnal Nasional ber-ISSN.
\end{abstract}

Kata Kunci: Pendampingan Inovasi, Pengelolaan Kelas, Agama Islam

\begin{abstract}
Abstrak. Sunan Kalijogo Jabung Junior High School is a school that is under the auspices of the Sunan Kalijogo Jabung Islamic Boarding School, so religious education is very emphasized on students who study at this school. So to realize this, service activities are carried out in the form of mentoring innovation in classroom management in learning Islamic religious education. The purpose of implementing this assistance is to be able to improve learning outcomes in the field of Islamic religious education so that it is of higher quality and has a good influence on students or teachers. Therefore, this assistance is focused on classroom management in order to improve learning outcomes, the implementation of this activity was carried out in July by inviting several competent resource persons in the field of Islamic religious education and classroom management. The output of this service is in the form of a book with ISBN and an article published in a National journal with ISSN.
\end{abstract}

Keywords: Innovation Assistance, Class Management, Islamic Religion

\section{PENDAHULUAN}

Pendidikan merupakan sebuah wahana pengetahuan bagi masyarakat dan menjadi kebutuhan dasar bagi mereka, sebab pendidikan dalam masyarakat modern atau masyarakat yang tengah bergerak kearah modern pada dasarnya berfungsi untuk memberikan kaitan 
antara anak didik dengan lingkungan sosiokulturalnya yang terus berubah dengan cepat (Namsah, 2000:23). Berpijak pada keadaan tersebut, dapat difahami bahwa pendidikan sangat besar artinya dalam kesinambungan hidup manusia dan tetap menjadi sarana inovasi bagi perubahan demi kualitas dan kesejahteraan hidup manusia.

Dalam Undang-Undang Republik Indonesia nomor 20 tahun 2003 tentang sistem pendidikan nasional pada Bab 1 Pasal 1 dikemukakan bahwa:

"Pendidikan adalah usaha sadar dan terencana untuk mewujudkan suasana belajar dan proses pembelajaran agar peserta didik secara aktif mengembangkan potensi dirinya untuk memiliki kekuatan spiritual keagamaan, pengendalian diri, kepribadian, kecerdasan, akhlak mulia, serta keterampilan yang diperlukan dirinya, masyarakat, bangsa, dan negara".

Langeveld dalam Aly (1999:13) telah mendifinisikan pendidikan adalah kegiatan membimbing anak manusia menuju pada kedewasaan dan kemandirian. Selain itu, Ki Hajar Dewantara dalam Ahmadi dan Uhbiyati (2001:33) Mengatakan bahwa pendidikan menuntun segala kekuatan kodrat yang ada pada anak-anak agar mereka sebagai manusia dan sebagai anggota masyarakat dapat mencapai keselamatan dan kebahagiaan yang setinggi-tingginya.

Seperti halnya dalam pernyataan diatas, yaitu Undang-Undang nomor 20 tahun 2003 tentang sistem pendidikan nasional Bab II Pasal 3 memberikan rumusan fungsi pendidikan nasional adalah:

"Pendidikan nasional berfungsi mengembangkan kemampuan dan membentuk watak serta peradaban bangsa yang martabat dalam rangka mencerdaskan kehidupan bangsa, bertujuan untuk berkembangnya potensi peserta didik agar menjadi manusia yang beriman dan bertaqwa kepada Tuhan Yang Maha Esa, berakhlak mulia, sehat, berilmu, cakap, kreatif, mandiri, dan menjadi warga negara yang demokratis serta bertanggung jawab."

M.D. Shipman dalam Namsah (2000:7) merumuskan bahwa fungsi pendidikan dalam masyarakat modern yang tengah membangun terdiri dari tiga bagian: pertama, sosialisasi yaitu wahana bagi intrasi/pembaruan anak didik kedalam nilai-nilai kelompok/nasional yang dominan; kedua pembelajaran yaitu mempersiapkan mereka untuk mencapai dan menduduki posisi sosial ekonomi yang akan membuat mereka mampu memainkan peran sosial ekonomis dalam masyarakat; ketiga, pendidikan yakni untuk menciptakan kelompok elit yang pada gilirannya akan memberikan sumbangan besar bagi kelanjutan program pembangunan. 
Sekolah sebagai suatu lembaga pendidikan formal secara sistematis merencanakan bermacam-macam lingkungan pendidikan. Lingkungan belajar yang baik adalah apabila bersifat menantang dan merangsang murid-murid belajar, memberikan rasa aman dan kepuasan, serta mencapai tujuan yang diharapkan. Wijaya, dkk (1997:27) mengatakan bahwa kualitas dan kuantitas belajar murid dalam pembelajaran bergantung pada muridmurid dalam kelas, bahan-bahan pembelajaran, perlengkapan belajar, kondisi umum, dan suasana di dalam kelas.

Dilihat dari sudut pandang konseptual atau realitas yang dapat di observasi secara nyata, proses pembelajaran di pengaruhi oleh beberapa faktor. Yaitu: manusia, yang meliputi guru, kepala sekolah, siswa, tenaga tata laksana, bahkan masyarakat, prosedur dan sistem yakni pembelajaran yang mencakup sumber dan bahan ajar; peralatan yakni media pembelajaran baik perangkat lunak maupun keras, dan lingkungan yang mencakup lingkungan kelas, sekolah, masyarakat dan lingkungan fisikal (Damin, 2002:43).

Dalam kegiatan belajar mengajar keberhasilan pengajaran sangat bergantung pada bagaimana kemampuan guru dalam mengatur proses belajar mengajar (PBM) yang merupakan suatu aspek dari lingkungan sekolah. Selain itu, keefektifan belajar siswa juga tergantung pada bagaimana suasana dan kondisi sebuah kelas, ruang kelas yang besar perlu disediakan sebagai tempat bekerja dan bermain, demikian pula dengan prinsipprinsip pengajaran baru seperti prinsip kebebasan berkembang, minat dan perhatian dalam bekerja harus diterapkan secara utuh (Wijaya, dkk, 1992:19).

Untuk itu, karena kondisi sebuah ruang kelas merupakan salah satu cara yang dapat menciptakan keefektifan dalam proses belajar mengajar, maka penataan dan pengeloaan ruang kelas perlu ditingkatkan dan dikembangkan agar seorang guru dapat menyediakan kondisi belajar yang optimal dengan suasana yang menyenangkan untuk mencapai tujuan pembelajaran.

Pengelolaan kelas adalah menciptakan dan memelihara kondisi belajar yang optimal dan mengembalikannya ke kondisi yang optimal jika terjadi gangguan, baik secara yang mendisiplinkan ataupun melakukan kegiatan remedial atau perbaikan" (Hasibuan dan Moejiono, 1993:42).

Selain itu, menurut Bakri (2001:22) pengelolaan kelas adalah:

"Proses dan pengorganisasian guru dalam menciptakan dan memelihara kondisi belajar yang optimal, dan keterampilan untuk mengembalikan kondisi belajar yang 
optimal, apabila terdapat gangguan dalam proses belajar mengajar baik yang bersifat gangguan kecil, sementara maupun gangguan yang bersifat besar dan berkelanjutan."

Perihal tentang pengelolaan kelas telah banyak dikemukakan oleh pakar pendidikan. Wijaya, dkk (1997:21) mengemukakan bahwa tahap-tahap pengelolaan kelas yang lazim dipakai masa kini sebagai landasan pembahasan meliputi:

a. Perencanaan (yakni, penciptaan penyusunan program dan perumusan kegiatan)

b. Pengorganisasian (yakni, pemanfaatan sumber dan pembagian tugas )

c. Pengarahan (yakni, motivasi, supervisi dan koordinasi)

d. Pengawasan (yakni, penganggaran, pelaporan dan evaluasi)

Namun permasalahan dalam pendidikan yang kita hadapi, banyaknya sistem pendidikan yang masih lemah dengan tujuan yang masih kabur, kurikulumnya belum serasi, relevan, suasana pembelajaran belum menarik dan membosankan (Wijaya, dkk, 1992:15).

Selain itu melihat kenyataan yang paling menonjol tentang bagaimana metode guru dalam menyampaikan materi pelajaran, yang sampai saat ini mayoritas masih hanya menggunakan metode ceramah tanpa menggunakan media atau alat pembelajaran yang telah ada, padahal menurut realita yang ada seorang siswa memiliki daya serap yang rendah terhadap informasi dan hafalan, dan kebanyakan dari mereka lebih mudah menangkap atau menerima sebuah pelajaran apabila mereka mengalaminya sendiri. Untuk itu sebuah inovasi dalam pendidikan sangat diperlukan terutama dalam hal pengelolaan kelas. Berawal dari permasalahan di atas, akhirnya pendamping tertarik untuk mengangkat sebuah judul "Pendampingan Inovasi Manajemen Pengelolaan Kelas Dalam Pembelajaran Pendidikan Agama Islam di SMP Sunan Kalijogo Jabung Malang, dengan disajikan kegiatan belajar mengajar dengan pola yang tidak sama, khususnya dalam hal pengeloaan kelas, dalam menggunakan sarana prasarana selalu disertai dengan sebuah praktek sehingga siswa dapat memperoleh pengetahuan dengan cara menemukan sendiri dan mereka dapat menghafal lebih cepat apa yang sedang mereka pelajari, juga adanya pola tata ruang kelas yang menyenangkan serta kondisi pembelajaran yang tidak selalu sama setiap harinya. Hal ini dimaksudkan untuk menghindari kebosanan dan kemalasan sehingga dapat menimbulkan semangat siswa dalam melakukan kegiatan belajar. 
Dengan adanya Inovasi Pengelolaan kelas inilah diharapkan program dan kegiatannya mampu membantu dalm meningkatkan suasana belajar yang efektif dan efisien sehingga belajar menjadi nyaman dan menyenangkan.

\section{METODE PELAKSANAAN KEGIATAN}

Metode adalah cara atau strategi untuk mewujudkan tindakan belajar mengajar, dan dalam fungsinya metode merupakan alat untuk suatu tujuan. Namsa (2002:5) mendefinisikan metode pembelajaran sebagai suatu cara yang dapat digunakan pendidik dengan berbagai teknik dalam proses berlajar mengajar agar materi pelajaran dapat di cerna dengan mudah serta efektif oleh peserta didik. Sehingga dapat dikatakan bahwa dalam kegiatan belajar mengajar tidak mungkin berlangsung tanpa adanya metode. Namun tidak semua jenis metode dapat digunakan dalam semua mata pelajaran, melainkan seorang guru harus dapat memilih ketetapan yang akan digunakannya sehingga sesuai dengan pembahasan yang sedang dilakukan. Maka itu metode yang dilaksanakan dalam pendampingan ini yakni menggunakan metode Team Work Employee Engagement, metode ini merupakan bentuk kerja tim dalam kegiatan pendampingan dengan tujuan meningkatkan kualitas kinerja guru mata pelajaran Pendidikan agama islam dalam manajemen pengelolaan kelas di SMP Sunan Kalijogo Jabung.

Istilah employee engagement pertama kali dipopulerkan oleh Kahn (1990), beliau menyatakan bahwa employee engagement sebagai keterikatan anggota organisasi dengan organisasi itu sendiri bukan hanya secara fisik, kognitif tetapi bahkan secara emosional dalam hal kinerjanya. Metode Team Work employee engagement menjadi sebuah gagasan pendamping dalam kegiatan ini, metode ini memiliki konsep bagaimana kerja tim ditumbuhkan dengan keterikatan para guru itu sendiri bukan hanya secara fisik, kognitif, tetapi juga secara emosional dalam hal kinerjanya. Maka metode ini adalah upaya meringankan beban lembaga dalam meningkatkan kualitas manajemen pengelolaan pembelajaran.

Adapun tahapan yang dilakukan dalam pendampingan ini, pertama pendamping terjun langsung sebagi pelaku dalam kegiatan pembelajaran, kedua membangun komunikasi yang interaktif dengan semua guru Pendidikan agama islam, ketiga pendamping membentuk tim khusus yang bertugas memeberikan materi pelatihan tentang manajemen pengelolaan kelas, keempat mengerjakan konsep manajemen pengelolaan kelas secara bersama-sama dengan 


\section{Khidinatuina \\ Jurnal Penelitian dan Pengabdian Hepada Masuarahat}

Institut Agama Islam Sunan Kalijogo Malang

P-ISSN: 2721-9607/ E-ISSN: 2721-947X

Volume 2 Nomor 2 Desember2021

panduan materi yang telah disampaikan oleh naras umber dan selanjutnya didiskusikan mengenai kendala dalam pembelajaran Pendidikan islam untuk mendapatkan solusi bersama, kelima penyelesaian akhir pendampingan manajemen pengelolaan kelas adalah melaporkan progress kepada lembaga sebagai bentuk tanggung jawab kelembagaan.

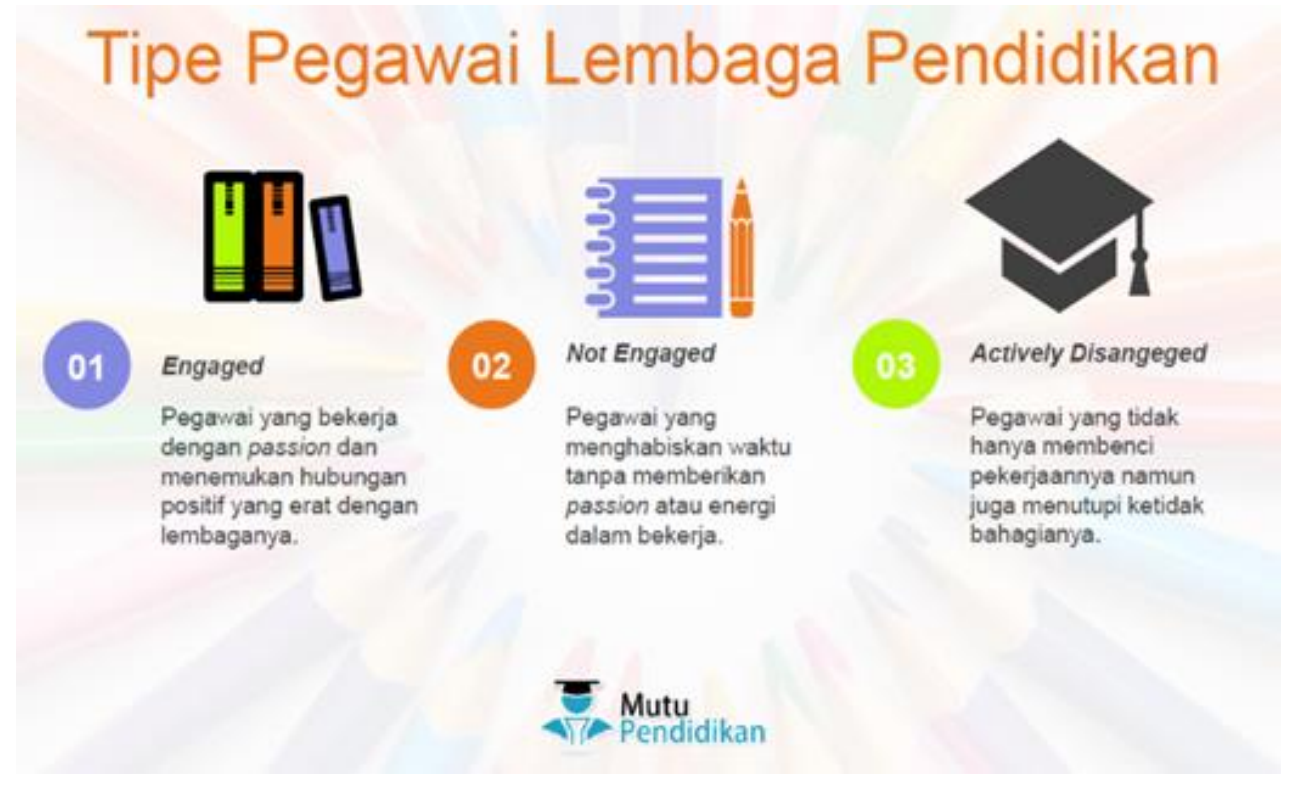

Gambar 2.1 Tipe pegawai Lembaga Pendidikan

\section{HASIL DAN PEMBAHASAN}

\section{Konsep Pelaksanaan}

Manajemen pengelolaan kelas merupakan kegiatan-kegiatan yang diupayakan oleh seorang guru untuk menciptakan situasi kelas yang kondusif dalam rangka pencapaian tujuan pembelajaran yang maksimal. Kegiatan ini merupakan suatu usaha yang sengaja dilakukan oleh guru supaya pembelajaran dapat berjalan efektif sehingga memungkinkan siswa untuk mengembangkan kemampuan semaksimal mungkin dan membentuk perilaku berbudaya. Manajemen kelas merupakan segala usaha yang diarahkan untuk mewujudkan suasana belajar mengajar yang efektif dan menyenangkan serta dapat memotivasi siswa untuk belajar dengan baik sesuai dengan kemampuan. Dengan kata lain manjemen kelas merupakan usaha secara sadar untuk mengatur kegiatan proses belajar mengajar secara sistematis. Agar hal tersebut dapat terwujud maka sangat perlu sekali diadakannya pendampingan manajemen pengelolaan kelas, yang pada pelaksanaan kegiatan pengabdian ini difokuskan pada guru mata pelajaran 


\section{Khidinatuina \\ Jurnal Penelitian dan Pengabdian Hepada Masuarahat \\ Institut Agama Islam Sunan Kalijogo Malang \\ P-ISSN: 2721-9607/ E-ISSN: 2721-947X \\ Volume 2 Nomor 2 Desember2021}

Pendidikan Agama Islam di SMP Sunan Kalijogo Malang. Pelaksanaan dilaksanakan pada awal tahun pelajaran, dengan tujuan agar dapat diterapkan pada saat awal mulai pembelajaran.

Luaran dari pengabdian ini yakni dalam bentuk buku yang dapat didownload pada link berikut:

https://drive.google.com/file/d/1DDcddqGgAi2Mm14saJEuvkYjIBWwJ 3q/view?usp=sharing

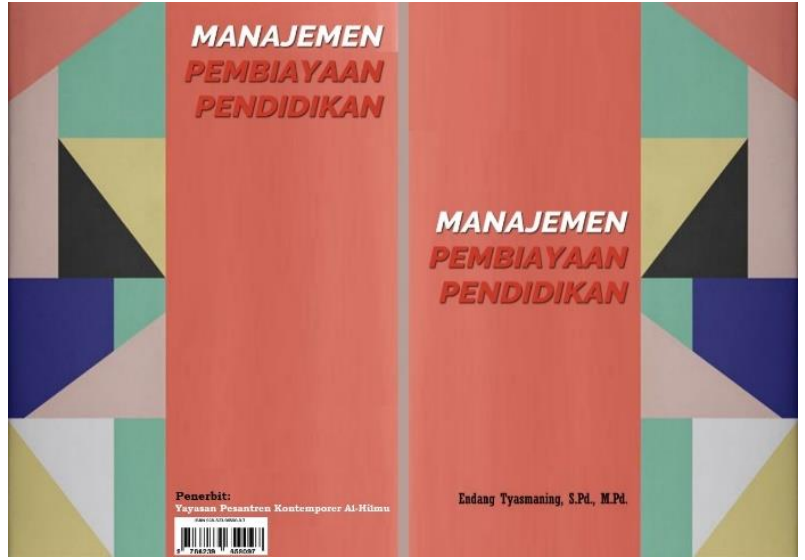

Gambar 6. Cover Buku hasil luaran pengabdian

Buku ini mencakup pembahasan yang dibagi dalam beberapa chapter, yaitu meliputi tentang:

A. Teori ekonomi pendidikan

B. Perencanaan pendidikan

C. Pembiayaan pendidikan

D. Jenis biaya pendidikan

E. Kondisi pembiayaan pendidikan

F. Faktor faktor yang mempengaruhi biaya pendidikan

G. Analisis biaya pendidikan

H. Konsep kualitas pendidikan

I. Efisiensi dalam pembiayaan pendidikan dalam rangka peningkatan kualitas pendidikan

J. Solusi perbaikan pengelolaan pembiayaan pendidikan islam

K. Pengertian pembiayaan pendidikan islam

\section{Dampak Perubahan}

Sekolah sebagai suatu lembaga pendidikan formal secara sistematis merencanakan bermacam-macam lingkungan pendidikan. Lingkungan belajar yang baik adalah apabila 
bersifat menantang dan merangsang murid-murid bejar, serta memberikan rasa aman dan kepuasan. Kualitas dan kuantitas belajar murid tergantung pada murid-murid dalam kelas, bahan-bahan pelajaran dan suasana didalam kelas, karena kondisi sebuah ruang kelas merupakan salah satu cara yang dapat menentukan keberhasilan pembelajaran, maka penataan dan pengelolaan ruang kelas perlu ditingkatkan dan dikembangkan. Oleh karena itu, sekolah berfungsi sebagai tempat anak dan pendidik melaksanakan kegiatan belajar mengajar. Dua kegiatan tersebut mempunyai tujuan untuk mengembangkan kemampuan intelektual sekaligus pembentukan pribadi anak.

Dari sebuah kegiatan belajar mengajar (KBM) seseorang yang belum melakukan dan yang sudah melakukan KBM sebenarnya tidak sama keadaannya. Dengan pesatnya kemajuan teknologi sumber pembelajaran mudah diperoleh namun beberapa guru atau pengajar tetap sangat diperlukan, sebab dalam KBM guru merupakan seseorang yang patut diteladani, baik oleh murid maupun masyarakat sekitarnya, maka tugas guru bukan hanya mentransfer pengetahuan tetapi juga membentuk kepribadian anak didiknya, dengan demikian tugas seorang guru sangatlah besar tetapi juga sangat mulia.

Seperti yang sudah terjadi di Sunan Kalijogo Jabung dalam melakukan berbagai macam inovasi pengelolaan kelas guna mengembangkan dinamika pembelajaran adalah melakukan inovasi dalam segi penataan ruangan kelas (kondisi kelas) dan model pembelajarannya, yang tidak lain bertujuan pelaksanaannya adalah mengembangkan dinamika/kegiatan pembelajaran. Adapun bentuk-bentuk tersebut adalah:

\section{A. Inovasi dalam segi model pembelajaran.}

Dalam inovasi penataan ruangan kelas ini, inovasi yang telah dilakukan oleh SMP Sunan Kalijogo Jabung Malang sebagai perkembangan, pembaharuan, dan perubahan guna meningkatkan mutu pendidikan. Dalam inovasi model pembelajaran ini, inovasi yang telah dilakukan di SMP Sunan Kalijogo Jabung, Penggunaan Model pembelajaran Integratif Learning (Tematik). 


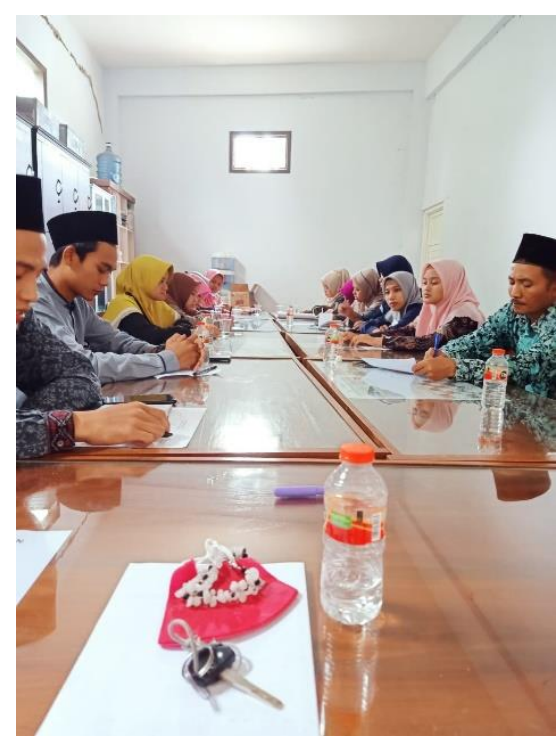

Gambar 1. Pendampingan pembelajaran Intregatuf Learning

Dalam bentuk pembelajaran Intregatuf Learning atau tematik di SMP Sunan Kalijogo Jabung, pembelajaran dilakukan dengan cara pengelompokkan tema dari mata pelajaran, yakni: dalam satu mata pelajaran, sebuah topic materi pelajaran tidak di potong-potong tetapi antara topic setiap satu pelajaran dengan pelajaran yang lain saling berhubungan. Misal: ketika dalam pelajaran Bahasa Indonesia yang bertemakan masalah budi pekerti, maka dalam pelajaran PPKn juga bertemukan kemurahan hati, dalam pelajaran IPA (sains) bertemukan benda padat dan cair, begitu seterusnya dengan mata pelajaran yang lain juga disesuaikan/disamakan. Hal ini dilakukan agar mata pelajaran yang ada dalam satu minggu dapat tercakup semua. Sehingga dari adanya kesamaan tema dalam setiap pelajaran dapat diterapkan sekaligus dalam satu hari, yakni di hari sabtu (one day discovery), dimana siswa diajak belajar diluar kelas dengan cara mengunjungi obyek tertentu, menjelajah, lading pertanian dan bertualangan sambil belajar. Dan dari semua mata pelajaran yang ada, hanya diambil satu yang menurut pertimbangan guru paling sesuai/cocok dengan tema (menonjol) untuk diterapkan oleh siswa.

Model pembejaran seperti ini, dilakukan dengan tujuan agar pembelajaran dapat berjalan optimal sesuai dengan tujuan kurikulum.

1. Penggunaan Model Pembelajaran Joiful Learning.

Dalam model pembelajaran joiful learning (belajar sambil bermain) di SMP Sunan Kalijogo Jabung, pembelajaran dilakukan dengan cara santai dan menyenangkan, yakni mempelajaru sebuah mata pelajaran dengan menerapkan pengalaman secara langsung sesuai 
dengan tema pelajaran yang ada. Misal: ketika dalam pelajaran PPKn dengan tema tolong menolong antar manusia, maka guru mengajak semua siswa turun langsung ke masyarakat bagaimana melakukan perbuatan tolong menolong sesame manusia suatu misal kerja bakti lingkungan, dan membantu anak yatim, dan pada saat pelajaran matematika, bab pengurangan. Maka guru menyuruh kepada setiap siswa untuk mencari dan membawah beberapa ikan, yang kemudian ikan-ikan tersebut di masukkan ke dalam aquarium yang di sediakan oleh guru, setelah itu guru menyuruh kepada siswa untu menhitung ada berapa jumlah ikan di dalam aquarium dan warnanya apa saja. Setelah itu guru memindahkan beberapa ikan yang ada di dalam aquarium ke tempat lain, kemudian guru menyuruh sekali lagi kepada siswa untuk menghitung kembali berapa jumlah ikan yang ada di dalam aquarium setelah mengurangi jumlahnya. Model pembelajaran seperti ini, dilakukan dengantujuan agar siswa mudah dalam memahami mata pelajaran.

2. Pengunaan Model Pembelajaran Life Skill.

Dalam model Pembelajaran Life Skill (kecakapan hidup) di SMP Sunan Kalijogo Jabung pembelajaran dilakukan dengan cara menyuruh siswa untuk melakukan segala hal dengan kemampuan yang mereka miliki. Misal: ketika dalam pelajaran bahasa Indonesia dengan tema/bab pasar. Maka guru memberi tugas kepada siswa untuk pergi ke pasar dan berbelanja, hal ini dilakukan dengan tujuan supaya siswa dapat mengetahui secara langsung bagainama keadaan sebuah pasar. Sekaligus siswa juga dapat mempelajari pelajaran matematika, yakni ketika mereka melakukan interaksi dengan penjual, dimana siswa melakukan pembayaran.

Model pembelajaran seperti ini, dilakukan dengan tujuan agar siswa sanggup dan mampu dalam melakukan sesuatu dengan sendirinya, dalam kata lain melatih untuk dapat mandiri.

3. Penggunaan Metode Pembelajaran Worksheet.

Dalam model pembelajaran Worksheet yang merupakan lembar kerja siswa. Pembelajaran dilakukan dengan cara guru memberikan satu lembar soal kepada semua siswa, yang di dalamnya tidak hanya berisikan soal-soal yang harus dijawab, tetapi juga terdapat sebuah gambaran yang harus mereka warnai. Misal: ketika dalam pelajaran bahasa Indonesia dengan tema lingkungan, maka guru memberi tugas/lembar kerja pada sisiwa, yang di dalamnya terdapat gambar berupa lingkungan yang kemudian mereka harus mewarnainya sekaligus menjawab pertanyaan-pertanyaanyang di dalamnya. Begitu juga dengan pelajaran yang lainnya. Hal ini dilakukan dengan tujuan agar siswa dalam mengerjakan latihan soal dari 
guru merasa nyaman sehingga tidak ada perasaan tertekan. Dari adanya berbagai macam inovasi model pembelajaran diatas, maka dapat disimpulkan bahwa dalam pembaharuan model pembelajaran di SMP Sunan Kalijogo Jabung sudah diniali berhasil, dengan melihat bukti-bukti diatas.

4. Dinamika Pembelajaran di SMP Sunan Kalijogo Jabung Malang

Dinamika Pembelajaran adalah kegiatan dalam belajar mengajar yang terjadi antara guru dengan murid sehingga terjadi interaksi, dimana murid aktif belajar dan guru aktif mengajar. Untuk mengetahui bagaimana perkembangan Dinamika pembelajaran di SMP Sunan Kalijogo Jabung Malang, pendamping sudah melakukan wawacara dan menyebarkan kepada siswa di SMP Sunan Kalijogo Jabung. Adapun dari wawacara dan angget diperoleh data sebagai berikut:

a. Peran serta siswa dalam proses belajar mengajar.

Dalam kegiatan belajar mengajar sebuah pembelajaran dapat dikatakan berhasil apabila siswa ikut berperan serta di dalamnya. Dan untuk mengetahui bagaimana keaktifan/peran serta siswa dalam pembelajaran di SMP Sunan Kalijogo Jabung Malang, pendamping telah menyebarkan angket kepadasiswa-siswi di SMP Sunan Kalijogo Jabung Malang. Dan apabila hasil 30 responden, 28 responden (80\%) menjawab senang terhadap semua mata pelajaran baik itu pelajaran praktek/uji coba maupun non praktek (teori) dan 2 responden $(20 \%)$ menjawab tidak senang dengan salah satu pelajaran. Selain itu, dari 30 responden $(100 \%)$ menjawab tidak senang apabila ada guru yang tidak hadir.

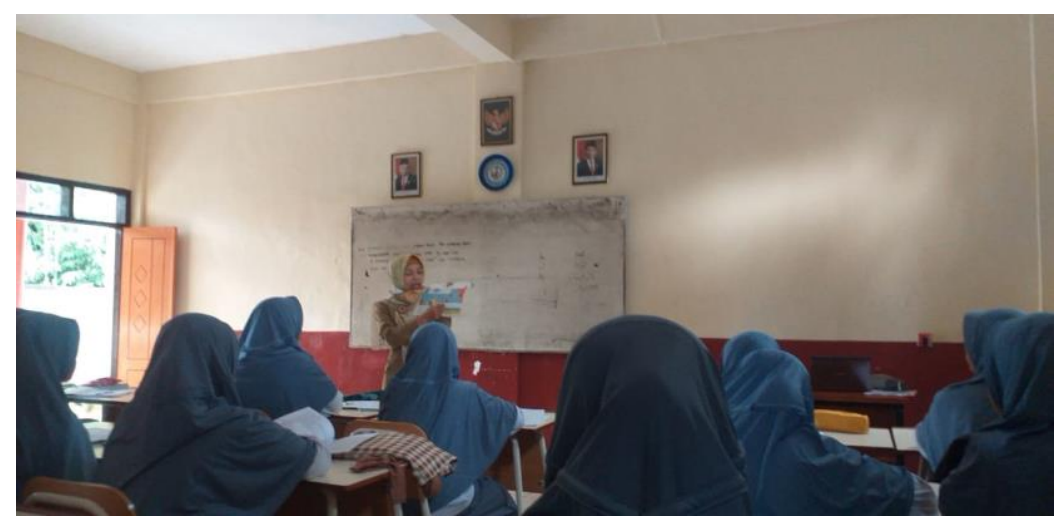

Gambar 2. Proses pelaksanaan Pembelajaran

Sehingga dapat dianalisis bahwa keefektifan/peran serta siswa dalam pembelajaran di SMP Sunan Kalijogo Jabung dikatakan senang dalam menerima semua mata pelajaran yang diajarkan oleh guru. 
b. Profesionalisme guru.

Guru dalam pelaksanaan pengajaran memiliki peran yang sangat penting. Kedisiplinan guru sangat menentukan dalam kelangsungan proses belajar mengajar di kelas maupun di luar kelas. Untuk itu, seorang guru hendaknya memiliki visi yang tepat dan aktif inovatif dalam pembelajaran, sehingga ia dapat menjadi guru yang professional. Dan salah satu cara yang dapat digunakan untuk mengukur keprofesionalismean guru adalah dapat dilihat dari pendidikan terakhir yang telah ditempih oleh seorang guru.

Dari data yang diperoleh dapat dianalisi bahwa tingkat profesionalisme guru di SMP Sunan Kalijogo Jabung, jika dilihat dari pendidikan terakhir maka dikategorikan cukup baik, dengan melihat sebagian besar yakni $50 \%$ dari merekan pendidikan terakhir adalah SI, S2, D2/D3 dan juga ada yang masih menyelesaikan SI, sedangkan jika diajarkan dikategorikan kurang, dengan melihat sebagian besar dari mereka dalam mengajar mata pelajaran belim sesuai dengan penddidikan terakhir.

c. Bentuk kurikulum.

Kurikulum merupakan alat yang sangat penting dalam rangka mewujudkan dan mencapai tujuan pembelajaran. Untuk itu, hendaknya sebuah kurikulum harus senantiasa luwes dan berinovatif serta disusun berdasarkan proses belajar yang terjadi pada diri siswa.

Untuk mengetahui bentuk kurikulum yang dipakai di SMP Sunan Kalijogo Jabung Malang, pendamping telah melakukan wawancara kepada kepala Madrasah dan kepada guru di SMP Sunan Kalijogo Jabung Malang. Dan diperoleh hasil responden, yang keseluruhan (10) responden (100\%) menjawab dalam proses belajar mengajar di SMP Sunan Kalijogo Jabung Malang, menggunakan kurikulum KTSP yaitu Kurikulum Tingkat Satuan Pendidikan yang dalam proses pembelajarannya dengan cara mengkontekstual atau menerapkan materi pelajaran dalam kehiduapan sehari-hari.

d. Penggunaan metode pengajaran

Dalam keberhasilan kegiatan belajar mengajar penggunaan metode pengajaran juga harus diperhatikan, sebab tanpa adanya metode yang tepat dalam pembelajaran, maka kegiatan belajar mengajar tidak akan dapat berjalan lancer sesuai dengan tujuan pembelajaran yang ingin dicapai. Untuk mengetahui penggunaan metode pembelajaran di SMP Sunan Kalijogo Jabung Malang, pendamping mewawancarai guru dari masing-masing guru menjawab hasilnya dari 5 responden, 2 responden, menjawab dalam proses belajar mengajar selalu menggunakan lebih dari enam metode secara bervariasi dan 2 responden 
dalam proses belajar mengajar hanya menggunakan metode cerah dan diskusi saja. Sehingga dapat dianalisis bahwa penggunaan metode dalam belajar mengajar di SMP Sunan Kalijogo Jabung Malang dapat dikatakan baik, dengan melihat sebagaian besar guru-guru menggunakan lebih dari enam metode secara bervariasi.

e. Penggunaan media pembelajaran

Dalam kegiatan belajar mengajar, sebuah media merupakan alat yang dapat membantu mengaktualisasikan atau menunjang situasi pembelajaran. Dengan menggunkan media pembelajaran, siswa akan lebih mudah menerima pelajaran yang disampaikan oleh guru. Selain itu, dengan adanya media pembelajaran, siswa tidak akan merasa jenuh dalam menerima materi dari guru saat proses belajar mengajar berlangsung.

Untuk mengetahui keseringan guru di SMP Sunan Kalijogo Jabung Malang dalam menggunakan media pengajaran, pendamping mewawancarai guru dan diperoleh hasil dari 7 guru menjawab selalu menggunakan media pengajaran dan dari 2 guru menjawab kadangkadang menggunakan media pengajaran. Sehingga dapat dianalisis bahwa penggunaan media pengajaran di SMP Sunan Kalijogo Jabung Malang dapat dikatakan dalam menggunakan media pengajaran sudah baik karena sebagian besar guru sudah banyak menggunakan media pengajaran dalam proses belajar mengajar.

f. Lingkungan sosial masyarakat.

Lingkungan sosial masyarakat secara tidak langsung terlibat dalam sebuah proses pendidikan. Dan tanpa melibatkan masyarakat sekitar, maka pelaksanaan pendidikan atau pengajaran akan terganggu, bahkan bisa merusak apabila mereka tidak diberitahu. Untuk mengetahui sejauh mana respon atau tanggapan masyarakat terutama wali murid dalam menerima pelaksanaan pengajaran di SMP Sunan Kalijogo Jabung, pendamping telah mewawancarai dari semua guru yang ada bahwasan dari mereka menjawab masyarakat sangat senang dalam menerima pelaksaan pembelajaran.

5. Faktor Pendukung dan Penghambat Upaya Guru dalam Inovasi Pengelolaan kelas untuk Mengambangkan Dinamika Pembelajaran di SMP Sunan Kalijogo Jabung Malang.

Bedasarkan proses pendampingan dengan beberapa guru di SMP Sunan Kalijogo Jabung Malang, bahwa faktor pendukung pengelolaan kelas, yaitu untuk mengembangkan dinamika pembelajaran di SMP Sunan Kalijogo Jabung Malang sebagai berikut:

a. Adanya kerja sama dan motivasi antar sesama guru dalam menciptakan mutu pembaharuan pembelajaran yang lebih baik. 
b. Adanya dukungan dari DEPAG dan DIKNAS.

c. Adanya sistem study banding dalam mengetahui segala macam pembaharuan dalam pendidikan.

d. Adanya sarana prasarana pembelajaran yang cukup memadai.

e. Adanya partisipasi dan keefektifan siswa dalam menarima setiap inovasi pembelajaran.

\section{Diskusi Keilmuan}

Dalam perkembangan dinamika pembelajaran di SMP Sunan Kalijogo Jabung Malang, jika ditinjau dari peran serta siswa, tanggapan masyarakat dan model pembelajaran dapat dikategorikan baik, dengan melihat sebagaian besar siswa dan masyarakat dan model pembelajaran dapat dikategorikan baik, dengan melihat sebagian besar siswa dan masyarakat senang dalam menerima inovasi pembelajaran yang dilakukan oleh guru dan banyaknya model pembelajaran yang dilakukan oleh para guru. Penilaian tersebut ditinjau dari beberapa aspek antara lain: 1) profesionalisme guru dapat dikategorikan baik, dengan melihat tingkat pendidikan terakhir sebagian besar guru adalah lulusan sarjana, 2) bentuk kurikulum yang digunakan dapat dikategorikan baik, dengan melihat kessesuaian antara kurikulum yang digunakan yakni kurikulum 2013 yang dalam proses belajar mengajar menerapkan materi pembelajaran dalam kehidupan sehari-hari.

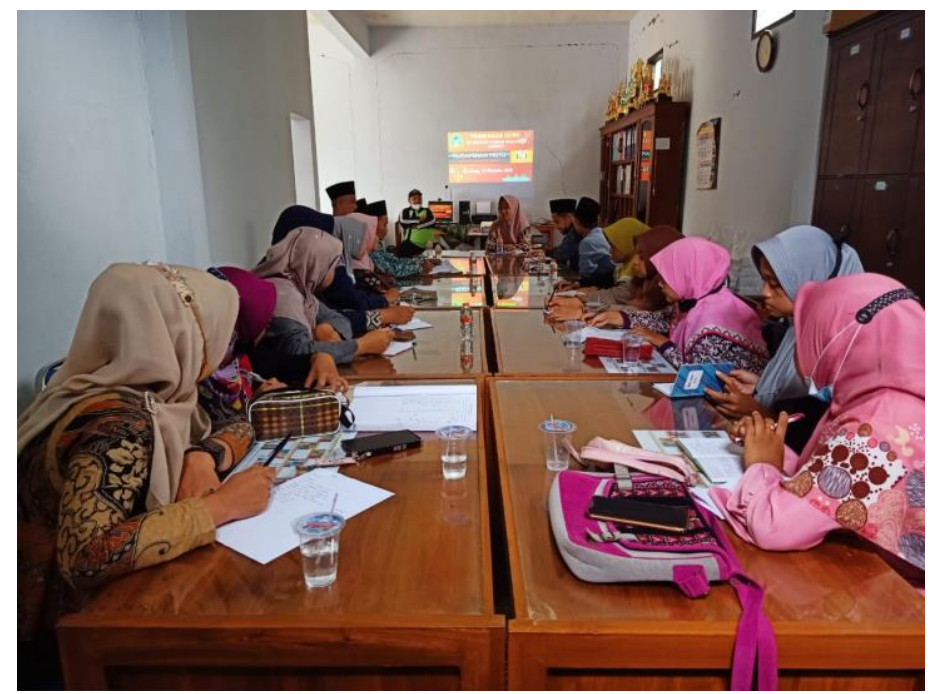

Gambar 3. Pendampingan Manajemen Pengelolaan Kelas 
Selain itu melihat kenyataan yang paling menonjol tentang bagaimana metode guru dalam menyampaikan materi pelajaran, yang sampai saat ini mayoritas masih hanya menggunakan metode ceramah tanpa menggunakan media atau alat pembelajaran yang telah ada, padahal menurut realita yang ada seorang siswa memiliki daya serap yang rendah terhadap informasi dan hafalan, dan kebanyakan dari mereka lebih mudah menangkap atau menerima sebuah pelajaran apabila mereka mengalaminya sendiri. Untuk itu sebuah inovasi dalam pendidikan sangat diperlukan terutama dalam hal pengelolaan kelas. Berawal dari permasalahan di atas, akhirnya pendamping tertarik untuk mengangkat sebuah judul "Pendamping Inovasi Manajemen Pengelolaan Kelas Dalam Pembelajaran Pendidikan Agama Islam di SMP Sunan Kalijogo Jabung Malang, dengan disajikan kegiatan belajar mengajar dengan pola yang tidak sama, khususnya dalam hal pengeloaan kelas, dalam menggunakan sarana prasarana selalu disertai dengan sebuah praktek sehingga siswa dapat memperoleh pengetahuan dengan cara menemukan sendiri dan mereka dapat menghafal lebih cepat apa yang sedang mereka pelajari, juga adanya pola tata ruang kelas yang menyenangkan serta kondisi pembelajaran yang tidak selalu sama setiap harinya. Hal ini dimaksudkan untuk menghindari kebosanan dan kemalasan sehingga dapat menimbulkan semangat siswa dalam melakukan kegiatan belajar.

Dengan adanya Inovasi Pengelolaan kelas inilah diharapkan program dan kegiatannya mampu membantu dalm meningkatkan suasana belajar yang efektif dan efisien sehingga belajar menjadi nyaman dan menyenangkan. Faktor pendukung inovasi pengelolaan kelas dalam mengembangkan dinamika pembelajaran di SMP Sunan Kalijogo Jabung Malang, adalah: adanya dukungan dari DEPAG dan DIKNAS, adanya sarana prasarana pembelajaran yang cukup memadai, adanya kerja sama dan motifasi antar sesame guru dalam menciptakan mutu pembelajaran yang lebih baik, adanya studi banding dan partisipasi siswa dalam menerima inovasi pembelajaran. Untuk itu sebuah inovasi dalam pendidikan sangat diperlukan terutama dalam hal pengelolaan kelas. Dengan adanya Inovasi Pengelolaan kelas inilah diharapkan program dan kegiatannya mampu membantu dalm meningkatkan suasana belajar yang efektif dan efisien sehingga belajar menjadi nyaman dan menyenangkan. Dalam inovasi penataan ruangan kelas ini, inovasi yang telah dilakukan oleh SMP Sunan Kalijogo Jabung Malang sebagai perkembangan, pembaharuan, dan perubahan guna meningkatkan mutu pendidikan.

Dalam inovasi model pembelajaran ini, inovasi yang telah dilakukan di SMP Sunan Kalijogo Jabung Malang, Penggunaan Model pembelajaran Integratif Learning (Tematik). 
Dalam bentuk pembelajaran Intregatuf Learning atau tematik di SMP Sunan Kaljogo Jabung, pembelajaran dilakukan dengan cara pengelompokkan tema dari mata pelajaran, yakni: dalam satu mata pelajaran, sebuah topic materi pelajaran tidak di potong-potong tetapi antara topic setiap satu pelajaran dengan pelajaran yang lain saling berhubungan. Misal: ketika dalam pelajaran Bahasa Indonesia yang bertemakan masalah budi pekerti, maka dalam pelajaran PPKn juga bertemukan kemurahan hati, dalam pelajaran IPA (sains) bertemukan benda padat dan cair, begitu seterusnya dengan mata pelajaran yang lain juga disesuaikan/disamakan. Hal ini dilakukan agar mata pelajaran yang ada dalam satu minggu dapat tercakup semua. Sehingga dari adanya kesamaan tema dalam setiap pelajaran dapat diterapkan sekaligus dalam satu hari, yakni di hari sabtu (one day discovery), dimana siswa diajak belajar diluar kelas dengan cara mengunjungi obyek tertentu, menjelajah, lading pertanian dan bertualangan sambil belajar. Dan dari semua mata pelajaran yang ada, hanya diambil satu yang menurut pertimbangan guru paling sesuai/cocok dengan tema (menonjol) untuk diterapkan oleh siswa.

\section{SIMPULAN}

Berdasarkan hasil pendampingan di lapangan, maka dapat disimpulkan bahwa inovasi pengelolaan kelas dalam mengembangkan dinamika pembelajaran di SMP Sunan Kalijogo Jabung Malang, dapat dikategorikan berhasil, terbukti dari adanya inovasi atau pembaharuan dalam segi penataan kondisi atau keadaan ruang kelas maupun metode pembelajaran. Dan melihat kenyataan yang terjadi banyaknya perubahan yang ada, baik dalam hal kondisi tempat duduk yang tidak hanya terdiri dari sebuah bangku melainkan juga adanya karpet, penggunaan media papan, dan media perkebunan di lingkungan sekolah, jumlah kelas dan juga banyaknya metode pembelajaran yang telah dilakukan.

Faktor pendukung inovasi pengelolaan kelas dalam mengembangkan dinamika pembelajaran di SMP Sunan Kalijogo Jabung Malang, adalah: adanya dukungan dari DEPAG dan DIKNAS, adanya sarana prasarana pembelajaran yang cukup memadai, adanya kerja sama dan motifasi antar sesame guru dalam menciptakn mutu pembelajaran yang lebih baik, adanya studi banding dan partisipasi siswa dalam menerima inovasi pembelajaran. 


\section{DAFTAR PUSTAKA}

Ahamadi, Abu dan Uhbiyati, Nur. 2001. Ilmu Pendidikan, Jakarta: PT. Rineka Cipta.

Aly, Hery Noer. 1999. Ilmu Pendidikan Islam. Jakarta: PT. Logos Wacana ILmu.

Arifin, Anwar. 2003. Memahami Paradigma Baru dalam UU SISDIKNAS, Jakarta: Departemen Agama RI.

Arikunto, Suharsimi. 2002. Prosedur Pendampingan "Suatu Pendekatan Praktek". Jakarta: PT. Rineka Cipta.

Arikunto, Suharsimi. 1998. Pengelolaan Kelas dan Siswa "Sebuah Pendekatan Evaluasi". Jakarta: CV. Rajawali.

Danim, Sudarwan. 2002. Inovasi Pendidikan " dalam Upaya Peningkatan Prpfesionalisme Tenaga Kependidikan". Bandung: CV. Pustaka Setia.

Darajat, Zakiyah. 1996. Metodologi Pendidikan Agama Islam. Jakarta: Bumi Aksara.

Departemen Agama RI. 1999. Petunjuk Peningkatan Mutu Pendidikan di Madrasah Ibtidaiyah (MI). Jakarta: Departemen Agama RI.

Faisal, Sanapiah. 2001. Format-format Pendampingan Sosial. Jakarta: PT. Raja Grafindo Persada.

Hadi, Sutrisno. 2001. Metodelogi Research, jilid 2. Yogyakarta: ANDI.

Hanalik, Oemar. 2003. Perencanan Pengajaran Berdasarkan Pendekatan Sistem. Jakarta: PT: Bumi Aksara.

Hasibuan dan Moedjiono.1993. Proses Belajar mengajar. Bandung: PT. Remaja Rosdakarya.

Moleong, Lexy J. 2002. Metodelogi Pendampingan Kualitatif. Bandung: PT. Remaja Rosdakarya.

Muhadjir, Noeng. 1998. Metodelogi Kualitatif. Yogyakarta: PT Bayu Indra Grafika.

Namsa, Yunus. 2000. Metodelogi Pengajaran Agama Islam. Ternate: Pustaka Firdaus.

Rakhman, Maman. 1993. Strategi dan Langkah-Langkah Pendampingan Pendidikan. Semarang: IKIP Semarang Press.

Santoso, Slamet. 1999. Dinamika Kelompok. Jakarta: Bumi Aksara.

Sedarmayanti dan Hidayat. 2002. Metodelogi Pendampingan Sosial Agama. Bandung: PT. Remaja Rosdakarya.

Suprayogo dan Tobroni. 2003. Metodelogi Pendampingan. Jakarta: CV. Rajawali.

Suryosubroto. 2004. Manajemen Pendidikan di Sekolah. Jakarta: PT. Rineka Cipta.

Tim Penyusun Panduan Skripsi. 2008. Panduan Penulisan Skripsi. Pasuruan: Universitas Yudharta Pasuruan.

Wijaya, C, Djadjuri, Djadja dan Rusyan, Tabrani. 1992. Upaya Pembaharuan dalam Pendidikan dan Pengajaran. Bandung: PT. Remaja Rosdakarya. 